\title{
Monoclonal Antibody NR-CO-04
}

National Cancer Institute

\section{Source}

National Cancer Institute. Monoclonal Antibody NR-CO-04. NCI Thesaurus. Code C29227.

A mouse monoclonal lgG3 antibody that reacts with the cytoplasm and cell surface of colonic adenocarcinoma and shows restricted normal tissue reactivity. NR-CO 04 has been suggested to mediate antibody-dependent cellular cytotoxicity (ADCC). 